\title{
UNDERSTANDING ENGLISH LANGUAGE TEACHERS' VIEWS OF TEACHER RESEARCH: A REPORT FROM INDONESIA
}

\author{
Anik Nunuk Wulyani ${ }^{\mathrm{a}}$, Ali Saukah ${ }^{\mathrm{b}}$, Abdul Syahid ${ }^{\mathrm{c}}$, IGA. Lokita \\ Purnamika Utami $^{\mathrm{d}}$, Susilo Susilo ${ }^{\mathrm{e}}$, Fiftinova ${ }^{\mathrm{f}}$, Gusti Nyoman Ayu Sukerti ${ }^{\mathrm{g}}$, \\ Astuti Azis ${ }^{\text {h }}$ Muhammad Amin ${ }^{i}$ \\ (anik.nunuk.fs@um.ac.id, balisaukah@yahoo.com, ${ }^{\mathrm{c} a b d u l . s y a h i d @ i a i n-~}$ \\ palangkaraya.ac.id, ${ }^{1}$ lokitapurnamika@undiksha.ac.id, \\ eolisusunmul@gmail.com, fiftinova@fkip.unsri.ac.id, ${ }^{g}$ ayusukerti@pnb.ac.id, \\ hazizastu@gmail.com, ${ }^{\mathrm{i}}$ aminmuhammad@unram.ac.id) \\ ${ }^{a}$ Universitas Negeri Malang (UM) \\ Jl. Semarang 5, Malang 65145, Jawa Timur \\ ${ }^{b}$ Universitas Muhammadiyah Kalimantan Timur (UMKT) \\ Jl. Ir. H Juanda No. 15, Samarinda 75124, Kalimantan Timur \\ ${ }^{c}$ Institut Agama Islam Negeri Palangka Raya \\ Jl. G. Obos, Palangka Raya 73112, Kalimantan Tengah \\ ${ }^{d}$ Universitas Pendidikan Ganesha, \\ Jl. A Yani no 67, Singaraja, Bali \\ ${ }^{e}$ Universita Mulawarman \\ Jl. Kuaro, Kampus Gn Kelua, Samarinda, Kalimantan Timur \\ ${ }^{f}$ Universitas Sriwijaya Jl. Raya Palembang-Prabumulih, Inderalaya, Ogan Ilir \\ 30662, Palembang, Sumatra Selatan \\ ${ }^{g}$ Politeknik Negeri Bali, Kampus Bukit \\ Jimbaran, Kuta Selatan, Kabupaten Badung, Bali \\ ${ }^{h}$ Badan Pengembang Sumber Daya Manusia (BPSDM) Makassar \\ Jl. Cendrawasih 233, Makassar, Sulawesi Selatan \\ ${ }^{i}$ Universitas Mataram \\ Jl. Majapahit 62, Mataram 83125, Nusa Tenggara Barat
}


Wulyani et al., English Language Teachers' Views of Teacher Research 363

\begin{abstract}
This article reports on a study investigating the perceptions of EFL teachers in schools and language courses (henceforth, teachers) and EFL lecturers in tertiary educational institutions (academic staff) from Indonesia regarding their definitions of and their engagements in teacher research. An online questionnaire was used to gather quantitative data from almost 400 EFL teachers and academic staff from Indonesia. The questionnaire was followed by in-depth interviews with some respondents who met the criteria set and agreed to be interviewed. Results from the study show that both teachers and academic staff align research with evidence-based practice, survey, literature-driven practice and professional communication, and observation-based popular article. In terms of engagements, most of the teachers and academic staff read research papers occasionally, and more academic staff did research compared to teachers. Research done by both teachers and academic staff is largely associated with internal and external factors, such as, professional awareness and professional obligation, with academic staff seem to receive more support to engage in research. The findings of the study provide insights for future continuous professional development (CPD) activities for English teachers and academic staff. The activities might involve exploring ways to integrate teacher research into teachers' and academic staff's teaching responsibilities and integrating teacher research into the shortterm and long-term goals of CPD.
\end{abstract}

Keywords: continuous professional development (CPD), EFL teachers and academic staff, teacher research

DOI: http://dx.doi.org/10.15639/teflinjournal.v32i2/362-388

Borg (2010, p. 395) defines teacher research as a systematic inquiry, qualitative and/or quantitative, conducted by teachers in their own professional contexts, individually or collaboratively (with other teachers and/or external collaborators), which aims to improve teachers' understandings of some aspects of their work, is made public, and has the potential to contribute to better quality. This definition is also reflected in the findings of some studies which suggest that EFL teachers research engagement is a part of teachers' efforts to improve their professionalism (Al-Maamari et al., 2017; Bai, 2018; Banegas, 2018; Borg, 2013, 2009; Borg \& Liu, 2013; Chen, 2015; Chow et al., 2015).

However, not all language teachers are familiar with the concept of teacher research. A study by Borg (2010) indicates that language teachers' understanding of teacher research is not sufficient. In addition, teachers are inclined to think that teacher research is the one done by others to them not the one that they do 
themselves. Their conception about teacher research as a professional development effort is not clear. This situation is affected not only by the internal factors within the teachers themselves, but also by the external factors related to their working conditions (Bai, 2018; Banegas, 2018; Borg, 2009, 2010). The internal factors involve how they view themselves as professional teachers (Banegas, 2018; Chow et al., 2015), their conceptions about research (Borg, 2010), and their limited knowledge and skills in doing research (Chow et al., 2015). Meanwhile, the external factors include the teachers' unfavorable working conditions (Banegas, 2018; Chow et al., 2015) and limited access to relevant literature (Borg, 2010).

Due to the internal and external factors, few EFL teachers are engaged in teacher research (Banegas, 2018; Borg, 2009; Borg \& Liu, 2013). This is unfortunate because teacher engagement in and with research can be of great benefit to their continuous professional development (Borg, 2013; Borg \& Sanchez, 2015; Çelik \& Dikilitaş, 2015; Dikilitaş \& Yayli, 2018; Medgyes, 2017; Richards \& Farrell, 2005).

Previous studies have discussed teacher research engagement by English language teachers at different levels, from global to regional and local ones. These studies are: Borg (2009) at a global level followed by Borg and Liu (2013) in the Chinese college level, Banegas (2018) in the Argentinian context, Chen (2015) in Taiwan, Al-Maamari et al. (2017) in Sultanate of Oman, and Tran et al. (2017) in Vietnam. Borg (2009: 358) seek to investigate the conceptions of research held by 505 teachers of English from 13 countries. He also investigated to what extent teachers said they read published research and did research. Borg and Liu's study (2013) investigated similar issues that have been examined by Borg (2009) in China. They were looking at the (1) degree of engagement with (through reading) and in (by doing) research among college English teachers (CETs), (2) reasons why they engaged actively or inactively in research, and (3) CETs' perceptions of their work place in supporting the research engagement. Even though Borg's study (2009) was aimed at portraying teachers' research engagement on global level, that is, involving $13 \mathrm{EFL} / \mathrm{ESL}$ countries, it fails to account for Indonesian EFL teachers. In a similar vein, Borg and Liu's study (2013) fails to account for what is happening in Indonesia. With over 560 college teachers at English language teaching departments all over Indonesia and unidentified number of EFL teachers and academic staff who must conduct research studies and publish them for earning academic degree as well as 
developing their teaching careers (Wiryawan, 2014), the portrait of Indonesian conditions and challenges could enhance the understanding of teacher research engagement.

Globally, this specific understanding may inform stakeholders on how to get teachers engaged in educational research more (Borg \& Liu, 2013), apply evidence-based or data-led teaching practice to improve their students' English proficiency, and encourage teachers' engagement in policy-driven and selfdriven professional development (Utami \& Prestridge, 2018). Locally, policy makers in Indonesia need to explore the potential and be given empirical evidence before a policy of teacher research can be recommended. Educational policy affects the way teachers approach professional development (Utami \& Prestridge, 2018). Thus, policy makers need empirical evidence that informs them regarding teachers' conceptions of research, their engagement in reading research publication and their activities in doing teacher research as well as the challenges they encounter to design a continuous professional development program that may work.

In addition to providing empirical evidence to support policy decision making in engaging English language teachers in teacher research, the present study also contributes to the body of knowledge about English language teachers' engagement in teacher research by adding to what has been found by Borg (2009). The contribution focused on finding empirical evidence in the Indonesian context, which is different from the contexts of the previous studies. Furthermore, it is important to note that the study has both English language teachers at schools and academic staff at universities, while previous studies mostly investigated teachers in general without distinctively mentioning both groups. In this vein, the results of the present study are expected to verify the conclusion of the previous studies that only a few of English language teachers are engaged in teacher research. Reasons for engaging or not engaging in teacher research in the Indonesian context can also be compared with the results of the previous research. The research reported here is thus aimed at investigating the perceptions of English language teachers and academic staff in Indonesian context regarding: (1) the characteristics of 'research', (2) the frequency of and reasons for their reading research publications, and (3) the frequency of and reasons for their conducting or not conducting research. 
366 TEFLIN Journal, Volume 32, Number 2, July 2021

\section{METHOD}

\section{Research Design}

The present study is a conceptual or constructive replication of studies done by Banegas (2018), Borg and Liu (2013), and Borg (2009, 2010). By conceptual replication, it means that the study "begins with a similar problem statement as the original study but employs a new research design to verify the original findings" (Abbuhl, 2011, p. 298). The design was selected as the study intended to understand the Indonesian English teachers' and academic staff's views and practices of teacher research as defined by Borg (2010).

This study follows a sequential explanatory multi-method strategy (Creswell, 2014) where a large amount of quantitative data was gathered through online survey and was followed by a qualitative data gathering procedure that was done through interviews. The in-depth interviews were conducted with a sub-sample of Indonesian English language teachers and academic staff who agreed to participate in the second phase of the study after the online survey.

\section{Participants}

The present study follows the research questions asked by Borg (2009, p. 360-361) but employs more targeted participants compared to Banegas (2018) and Borg's (2009) studies. The participants consist of EFL teachers in schools and language courses and EFL academic staff in tertiary educational institutions in Indonesia.

In the first phase of the study, the survey stage, almost 400 Indonesian teachers and academic staff $(\mathrm{N}=398)$ participated in the online survey. The teacher participants were 259 out of 398 respondents (65\%). The academic staff participants were 139 out of 398 respondents (34.9\%).

In the second phase of the study, the in-depth interview stage, there was a total of 20 participants. They consisted of 11 EFL teachers and nine academic staff. A nonprobability sampling procedure, purposive sampling, was used to choose the participants of the in-depth interview. The purposive sampling (Battaglia, 2008) allowed a selection of participants from the population of teachers and academic staff who participated in the online survey to be interviewed in the in-depth interview. The interviews were purposively targeted to Indonesian teachers and academic staff whose years of experience range from 5 to 24 years to ensure that they had sufficient working experience, were not 
going to retire soon, representative of the participants from different part of Indonesia, and had research as part of their routine teaching responsibilities as mandated by the Indonesian Ministry of Education and Culture. The findings of the study are expected to provide a complete picture of research engagement and practices that Borg (2009), Borg and Liu (2013) and Banegas (2108) have initiated.

\section{Research Instruments}

\section{The Survey Questions}

The online survey instrument was adapted from Borg (2009). The number of the questions and wording of the survey were similar to Borg's instrument with some modification on the language to match the teaching and learning situations in Indonesia. The researchers had obtained a written agreement from the creator of the questionnaire, Simon Borg. Before the questionnaire was distributed, it was validated by members of the research team and was tried out. The draft of the online questionnaire was passed to several teaching staff and also teachers in East Java, Indonesia for feedback and comments. Some revisions were made based on their feedback and comments. The revisions encompassed the aspects of user friendliness of the online version of the questionnaire.

The survey consists of seven main questions on: participants' background information (e.g., the country where they are from and their administrative responsibilities in the institution), research scenarios, characteristics of good quality research, research culture, reading research, doing research, and research support (see Appendix 1). The section on research scenarios in the survey was placed in the beginning of the survey. Ten scenarios (see Appendix 3) were introduced in the survey to elicit the participant's views on the kind of activities which can be called research. There were no wrong or right answers. One additional section is added on whether participants are interested in the next phase of the study (in-depth interview).

\section{The Interviews}

The interviews were semi-structured interviews where some sets of questions (or interview guide) as the basis for the interviews were prepared (Friedman, 2012, p. 188). Friedman (2012) further stated that the follow-up 
questions may deviate from the guide if needed. This was done to go after topics that arise during the course of the interviews.

The interviews were carried out in Indonesian and/or English and lasted for about 30 to 60 minutes. The respondents were allowed to choose either language or even switch between the languages. This was done to ensure that the respondents understand the questions well and feel comfortable during the interview sessions. Whenever direct communication via the telephone voice call was not possible because of bad internet connection, voice recording (which was later sent via WhatsApp) was used as long as the participants were able to respond to the questions well. The questions addressed cover similar topics as the questions in the online survey. This is a way of confirming respondents' answer but with more allowance to explore the data further (see Appendix 2).

\section{Data Collection and Analysis Procedures}

The data were collected in two phases from April 2018 to February 2019. Information on the study and consent forms were integrated in the survey questionnaire. Thus, potential participants (of the survey and interview) were well informed from the beginning of the study. In April 2018, the online survey, which is a Google Forms survey, was launched via social media (WhatsApp, Instagram and Facebook) and emails. Three hundred ninety-eight English language academic staff and teachers from Indonesia completed the online survey by early November 2018. The data from the online survey were completed with qualitative data gathered from the in-depth interviews. The interviews were carried out in the end of 2018 to early 2019 with 20 interviewees. The 20 interviewees were chosen based on their agreement to participate in the second phase of the research and the criteria that have been described earlier.

To analyze the collected survey and interview data, some steps were done. Since the survey data were gathered through Google Form and the responses were exported into a spreadsheet, the process of turning the data into percentages, charts or tables was carried out quite easily. After the data were sorted and categorized, percentages, charts or tables were created to visualize the trends of study.

For the interview data, they were first transcribed verbatim and some parts in Indonesian were translated into English by the researchers for the purpose of analysis. Then, the English version of the interview data had to go through initial coding before being analyzed using thematic analysis (Braun \& Clarke, 2006). 
Wulyani et al., English Language Teachers' Views of Teacher Research 369

To ensure the reliability of the data, some members of the research team exchanged and read each other's initial coding and analyses, and the results were finalized by the other team members.

\section{FINDINGS AND DISCUSSION}

\section{Findings}

This section presents the findings of the research. They are reported on the basis of the two utilized research instruments, an online survey questionnaire and a follow-up interview. The online survey reveals the characteristics of research as understood by the EFL teachers and academic staff and the in-depth interviews indicate the degree to which teachers and academic staff read and not reading research publication and reasons for their conducting and not conducting research as well as their perceptions of the research culture in their institutions.

\section{Demographic Information of the Respondents}

The first part of the online survey was to gather information on the participants' educational and professional backgrounds. A total of 398 teachers and academic staff participated in the online survey. Most of the participants (N $=259$ ) or $65.1 \%$ of them are teachers. The rest of the participants, $34.9 \%$ or 139 participants, are academic staff. They came from different parts of Indonesia. Table 1 shows the detailed demographic information of both groups.

Table 1. Participants' Demographic Information

\begin{tabular}{|l|l|l|}
\hline $\begin{array}{c}\text { Demographic } \\
\text { information }\end{array}$ & \multicolumn{1}{|c|}{ EFL Teachers (N = 259) } & EFL Academic Staff (N = 139) \\
\hline $\begin{array}{l}\text { Educational } \\
\text { background }\end{array}$ & $\begin{array}{l}\text { Doctorate degree (0.4\%) } \\
\text { Master's degree (16.6\%) } \\
\text { Bachelor's degree }(54.8 \%) \\
\text { Others (28.2\%) }\end{array}$ & $\begin{array}{l}\text { Doctorate degree }(17.2 \%) \\
\text { Master's degree }(65.4 \%) \\
\text { Bachelor's degree }(11.5 \%) \\
\text { Others (5.9\%) }\end{array}$ \\
\hline Workplace & $\begin{array}{l}\text { Public schools (48.6\%) } \\
\text { Private schools (45.9\%) } \\
\text { Informal English courses } \\
\text { and tutoring (5.5\%) }\end{array}$ & $\begin{array}{l}\text { Public universities }(56.1 \%) \\
\text { Private universities (43.9\%) }\end{array}$ \\
\hline $\begin{array}{l}\text { Employment } \\
\text { type }\end{array}$ & $\begin{array}{l}\text { Full-timers (62.9\%) } \\
\text { Part-timers (32.4.1\%) } \\
\text { Others (4.7\%) }\end{array}$ & $\begin{array}{l}\text { Full-timers }(86.3 \%) \\
\text { Part-timers (12.2\%) } \\
\text { Others (1.5\%) }\end{array}$ \\
\hline
\end{tabular}


370 TEFLIN Journal, Volume 32, Number 2, July 2021

\begin{tabular}{|l|l|l|}
\hline $\begin{array}{c}\text { Demographic } \\
\text { information }\end{array}$ & \multicolumn{1}{|c|}{ EFL Teachers $(\mathbf{N}=\mathbf{2 5 9})$} & EFL Academic Staff $(\mathbf{N}=\mathbf{1 3 9})$ \\
\hline Years of & $>10$ years $(41.3 \%)$ & $>10$ years $(54 \%)$ \\
teaching & $5-9$ years $(18.5 \%)$ & $5-9$ years $(27.3 \%)$ \\
experience & $0-4$ years $(40.2 \%)$ & $0-4$ years $(18.7 \%)$ \\
\hline Professional & Certified $(58.3 \%)$ & Certified $(77.7 \%)$ \\
certification & Not certified $(41.7 \%)$ & Not certified $(22.3 \%)$ \\
\hline $\begin{array}{l}\text { Perceived } \\
\text { administrative }\end{array}$ & Considerable $(31.7 \%)$ & Considerable $(30.2 \%)$ \\
responsibilities & Little $(20.5 \%)$ & Moderate $(51.8 \%)$ \\
\hline
\end{tabular}

Meanwhile, the interview participants, as described earlier, were selected based on the following criteria: years of experience range from 5 to 24 years, not going to retire soon, representatives of the participants from different part of Indonesia, and research is part of their routine teaching responsibilities. Twenty out of them agreed to do the interview through mobile phone or video call. The 20 interviewees were 11 teachers and nine academic staff. They came from different parts of Java, Kalimantan (Borneo), Sumatra, Bali, and also Sulawesi.

\section{Characteristics of Research Viewed by the Participants}

The second part of the online survey elicited the participants' views on the provided 10 scenarios categorized as research. The teachers and academic staff assessed the scenarios using a four-point Likert scale ranging from "definitely not research" to "definitely research." To portray the participants" $(N=398)$ conceptions of research, the scenarios are sorted according to the scale of "definitely research" to "definitely not research" (see Table 2). Interestingly, there is a strong tendency that academic staff viewed most of the scenarios as "probably research", while teachers tended to view most of the scenarios as "probably not research". Eight scenarios were perceived as probably research by academic staff and four scenarios were perceived as probably research by teachers.

The findings from the online questionnaire showed that Scenarios 4, 6, 2, 5, and 10 ranked $1^{\text {st }}$ to $5^{\text {th }}$ consecutively among academic staff, and Scenarios 6, 4, 2 and 5 ranked $1^{\text {st }}$ to $4^{\text {th }}$ respectively among teachers. While academic staff considered two scenarios (Scenarios 1 and 8) as probably not research, teachers perceived six scenarios (Scenarios 1, 10, 3, 7, 8, \& 9) as probably not research. In other words, both teachers and academic staff agreed that Scenarios 1 and 8 
should be categorized as probably not research. However, they had dissimilar ideas about Scenarios 3, 7, 9 and 10. Academic staff perceived those scenarios as probably research but teachers viewed them as probably not research.

Table 2. Overall Academic Staff and Teachers' Perception of Research Scenarios

\begin{tabular}{|c|c|c|c|c|c|c|c|c|}
\hline \multirow{3}{*}{ 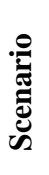 } & \multicolumn{4}{|c|}{ Academic staff $(\mathrm{N}=139)$} & \multicolumn{4}{|c|}{ Teachers $(\mathbf{N}=259)$} \\
\hline & \multicolumn{2}{|c|}{ Research } & \multicolumn{2}{|c|}{ Not research } & \multicolumn{2}{|c|}{ Research } & \multicolumn{2}{|c|}{ Not research } \\
\hline & $\begin{array}{c}\text { Definitely } \\
(\%)\end{array}$ & $\begin{array}{c}\text { Probably } \\
(\%)\end{array}$ & $\begin{array}{c}\text { Definitely } \\
(\%)\end{array}$ & $\begin{array}{c}\text { Probably } \\
(\%)\end{array}$ & $\begin{array}{c}\text { Definitely } \\
(\%)\end{array}$ & $\begin{array}{c}\text { Probably } \\
(\%)\end{array}$ & $\begin{array}{c}\text { Definitely } \\
(\%)\end{array}$ & $\begin{array}{c}\text { Probably } \\
(\%)\end{array}$ \\
\hline 1 & 9.4 & 31.7 & 12.2 & 46.8 & 10.0 & 35.5 & 11.2 & 43.2 \\
\hline 2 & 2.2 & 74.1 & 3.6 & 20.1 & 0.4 & 66.4 & 6.9 & 26.3 \\
\hline 3 & 17.3 & 34.5 & 17.3 & 30.9 & 17.4 & 20.8 & 27.0 & 34.7 \\
\hline 4 & 0.0 & 92.1 & 1.4 & 6.5 & 3.5 & 70.3 & 3.9 & 22.4 \\
\hline 5 & 2.9 & 58.3 & 8.6 & 30.2 & 5.0 & 47.9 & 10.0 & 37.1 \\
\hline 6 & 1.4 & 88.5 & 1.4 & 8.6 & 1.5 & 77.2 & 3.5 & 17.8 \\
\hline 7 & 21.6 & 33.1 & 21.6 & 23.7 & 27.4 & 15.4 & 23.6 & 33.6 \\
\hline 8 & 18.0 & 21.6 & 23.7 & 36.7 & 18.1 & 20.5 & 28.2 & 33.2 \\
\hline 9 & 11.5 & 36.0 & 22.3 & 30.2 & 18.5 & 28.2 & 22.8 & 30.5 \\
\hline 10 & 6.5 & 45.3 & 12.9 & 35.3 & 11.6 & 33.2 & 17.8 & 37.5 \\
\hline
\end{tabular}

Most of the participants from both groups considered the following scenario as probably research, that is: Scenario 4 (giving out questionnaire and analyzing its results using statistical analysis), Scenario 6 (comparing and finding out which one out of two teaching methods was more effective than the other), Scenario 2 (a teacher tried out a new teaching approach, recorded her/his teaching and collected samples of her/his learners' written work is also considered as research), and Scenario 5 (two teachers observed each other's lessons, discussed their notes and wrote a short article).

On the other hand, Scenarios 1 and 8 were perceived by both groups as probably not research. Scenario 1 is when a teacher noticed that an activity, she used in class did not work well and tried something different in her next lesson, and Scenario 8 is when a teacher gave a feedback form to the students.

The findings from this online survey were supported by the results of the in-depth interviews in which teachers appeared to define research as a formal 
endeavor to investigate what issues arise in and outside their classroom (see Scenarios 6 and 4). Upon being asked if she did any research at all, one teacher from Bali, Ketut (pseudonym), said that she did descriptive research during her undergraduate study. She explained:

Well, my study was looking at the correlation between the students' final examination and their English proficiency. I found out that there was no correlation between the two variables. I concluded that the students' English proficiency had to be improved and we needed to motivate them to be more active. How can we improve their interest in learning?

This is an example of a teacher who did research to investigate a correlation between two phenomena that were common in the Indonesian teaching and learning context, that is, students' performance in their national exam and their day-to-day competence.

Another teacher, Yulia (pseudonym), who is teaching at a language course in Palembang, Sumatra, stated that it was a must for her and her colleagues to do classroom action research (CAR) every year. She defined CAR as a type of research commonly triggered by the issues in the classrooms. CAR may be a case study, a descriptive study, or comparing and contrasting teaching methodology. The variation within the study itself is dependent upon the researchers' interest.

Altogether, these findings showed that the EFL academic staff and teachers' conceptions of research evolved around the ideas of comparing and contrasting ideas and finding which one is a more effective one (Scenario 6), giving questionnaire (Scenario 4), trying new approach (Scenario 2), and observing classes and writing an article in academic journal (Scenario 5).

\section{ELT Teachers and Academic Staff's Frequency of Reading or Not Reading Research Publications}

Most EFL teachers and academic staff did not read published language teaching research frequently. The results of the online questionnaire showed that most teachers $(59.4 \%)$ and academic staff $(65.9 \%)$ did not frequently read research publication (see Figure 1). Those who said they often and frequently read published language teaching research mentioned the following sources of reading: web-based sources of research, academic journals (e.g., TESOL 
Quarterly), professional journals, (e.g., ELT Journal), newsletters (e.g., IATEFL SIG Newsletter), professional magazines (e.g., ET Professional), and books.

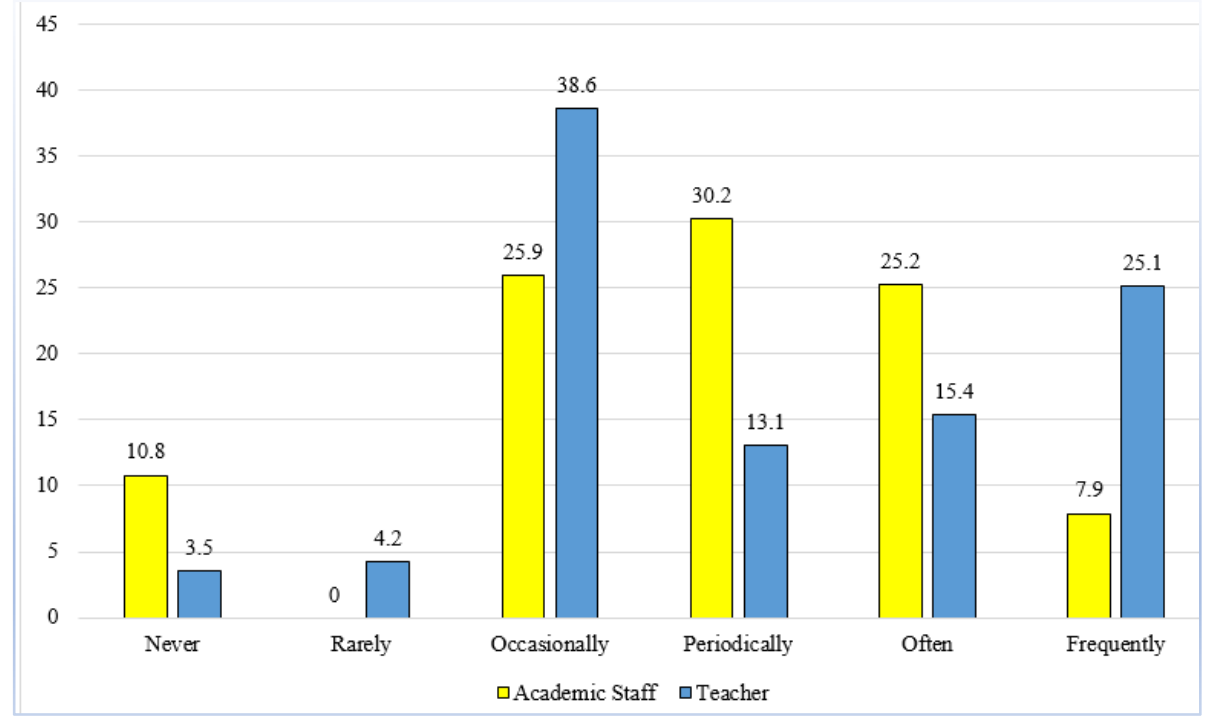

Figure 1. Percentage of teachers and academic staff's frequency of reading published language teaching research

The in-depth interview was focused on investigating whether the EFL teachers and academic staff (1) read research reports and the reasons behind their statements, and (2) received any incentives, facilities, or assistance in reading and doing research from their institutions. It was found that the reasons why ELT teachers and academic staff read the research reports were: (a) looking for some recent developments in teaching methods to improve their teaching, (b) looking for ideas for the teachers' own research or proposals for postgraduate studies, (c) personal interest, (d) writing their $\mathrm{PhD}$ thesis, (e) writing articles, (f) writing their own research reports, and (g) doing self-reflection on their teaching practice.

Regarding the teachers' effort to look for some recent developments in teaching methods, Nyoman (pseudonym), a male teacher from Bali stated: 
First, I want to know the development in a particular field, for example I will see the field, then, what is recent in the field. First, I will see the year, yes, what is the latest development in my field. That's what I am going to read.

Made (pseudonym), a vocational school teacher from Bali also had similar ideas. She said that she was not happy with the idea of teaching using Grammar Translation Method (GTM). Thus, she read journal articles so that she could find strategies and media to connect her teaching and her subjects with her students' lives. On personal interest, Naning (pseudonym), a female academic staff from Surabaya said:

Yes, I am reading (journal) articles that can be accessed in the internet. They can be in the form of dissertations or thesis, as long as they are relevant to the field I am learning: teacher professional development or teaching using technology.

The reasons given by the participants, both from teachers and academic staff, for not reading research reports were: (a) lack of the need for reading journal articles, (b) lack of interest, (c) lack of motivation, (d) lack of competence, and (c) lack of time.

Endah (pseudonym), one junior high school teacher affirmed that she has never read research reports like dissertation or theses, as she viewed research reports used too formal language and were less practical. She stated:

Personally, I haven't read any research reports like dissertations for my teaching. I usually look for a book or online reading materials that is more practical in terms of language and they are not too formal.

Problems with understanding journal articles are also parts of the reasons for not reading research reports, as described by Hilmi (pseudonym), a teacher from Gowa, Sulawesi. She said that her ability to read was very low. She could only concentrate on what she read for 30 minutes, and after that she would lose her concentration. She perceived that her age was the reason for her slow reading capacity.

In brief, research engagement is present in the lives of both teachers and academic staff although some challenges persistently prevented them from reading published research reports. The sources that they read varied from webbased sources of research, academic journals, professional journals, books, newsletters, to professional magazines and books. The issues that challenged the teachers and academic staff to read research reports and or publications ranged 
from believing that they do not need journal articles to having lack of time to read.

\section{ELT Teachers and Academic Staff's Research Engagement: Conducting or Not Conducting Teacher Research}

The online questionnaire showed that about $56.1 \%$ out of 139 academic staff often and frequently do research, while about $46.3 \%$ out of 259 teachers often and frequently do research (see Figure 2). The next highest percentages go to the teachers $(30.1 \%)$ and academic staff $(20.1 \%)$ who occasionally do research and periodically do research (10.8\% of teachers and $15.8 \%$ of academic staff). The reasons for their doing research were similar. These included: (a) professional obligation (because it is good for my professional development), (b) professional awareness (to contribute to the improvement of department/institution), (c) promotion for higher job ranks (because it will help me to get a promotion), (d) competitive atmosphere (because other teachers can learn from the findings of my work), (e) financial incentive, (f) personal passion (I enjoy it), and (g) solving problems in the class (to find better ways of teaching).

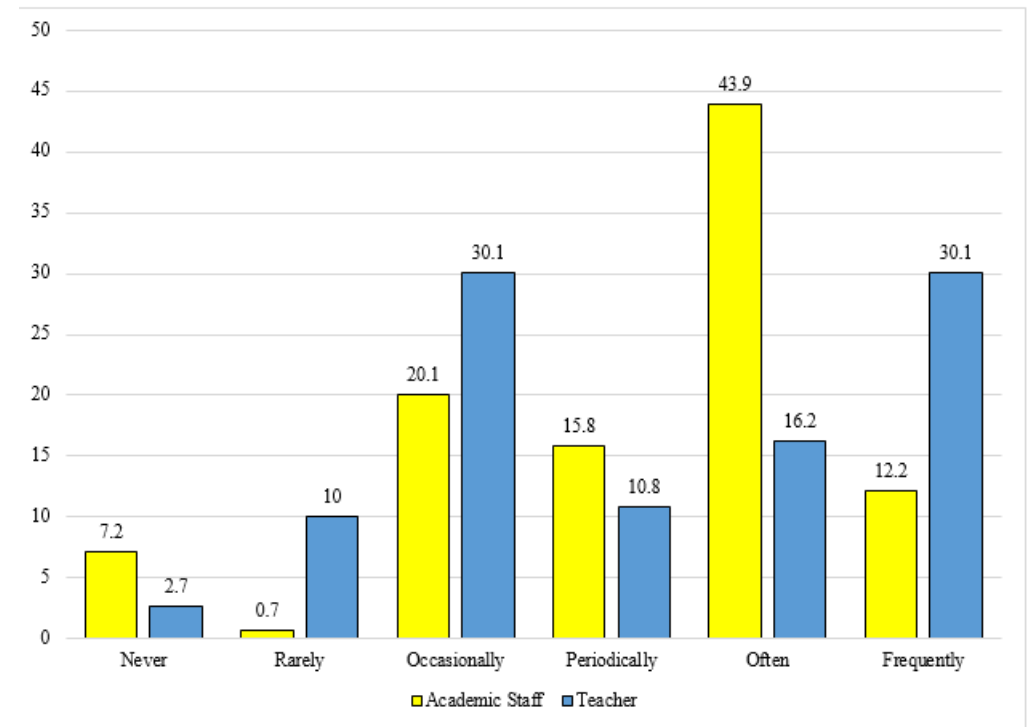

Figure 2. Teachers' and academic staff's frequency of doing research 
In the interview, three teachers and two academic staff mention that research is a professional obligation for every educator, especially if she or he wants to get a promotion. Doing research or publishing an article based on the research is a must. Alsa (pseudonym), one of the lecturers, said that there is a demand (to do research) as parts of the responsibility as academic staff, and she also has an obligation to improve herself.

A very interesting view came from one of the academic staff (Naning, a pseudonym) who said that doing research is more about improving herself and her teaching strategy rather than about being promoted. She stated:

Currently, I'm part time lecturer in Universitas Terbuka (Open University), sometimes I conduct small research related to my teaching in my class. Even though this is not obligation because I'm still part time lecturer, I try to make myself write an article so I can examine myself about how my class was going so far or as note for self-reflection about the teaching strategy I used in my class.

Meanwhile, the reasons for the participants' not doing research included: (a) lack of interest, (b) lack of time, (c) lack of motivation, (d) lack of incentives, (e) lack of supports, (f) lack of academic atmosphere, and (g) lack of need to do research.

Endah (pseudonym), a junior high school teacher said in the interview that she was challenged by lack of motivation, time and supports. Another teacher (Hilmi, pseudonym) reported that she did not do any research and neither did her colleagues because they felt that they did not have sufficient knowledge to do research at school. She further admitted that time was not the only challenge; she also felt that she did not have the ability to read research reports and let alone do the research. She stated:

Yeah, the first one is time and second one is that availability of those kind of writings, you know I cannot do it at school and I don't know how to find it. And my ability to read is very low, I can only concentrate on what I read for 30 minutes, and after that I will lose my concentration.

EFL teachers and academic staff had different answers about the incentives, facilities or assistance they received from their institutions. The teachers generally said that they did not receive incentives or support other than free WiFi at schools or training on how to write good research reports. The academic staff, on the other hand, said that they received ample support from their institutions to engage in professional development programs such as trainings, 
workshops or seminars. Their institutions also had better Internet connections and libraries, and they also received financial rewards.

One of the academic staff (Alsa, pseudonym) however suggested that the academic staff need to have mentors who would continue guiding and encouraging them to write after they attended some trainings. She stated:

.... if you asked me about research, I think so far, the faculty always inform us about the chance of doing research supported or funded by the university or from different institution and $\mathrm{I}$ think it is very good but dealing with reading or supporting the academic staff to read and there is nothing to do (sic). I mean, it is the lecturer who have to do it by themselves and actually reading is related to writing, yes? The institution or the faculty only give us or try to or support us by inviting some experts who later on check our manuscript and then gives comments. That's all but I think it is important not only giving comments (sic). I think it is important to have a kind of mentoring or pendamping so that we are really supported in writing and also doing research....

Thus, teachers and academic staff appeared to be challenged by different issues including internal issues, such as motivation and interest to do research and external issues, such as lack of supports and heavy teaching loads.

To summarize, English teachers at schools and academic staff at universities have various reasons for their reading or not reading research publications and for doing or not doing research. However, the university academic staff revealed that they received better supports compared to the teachers at schools.

\section{Discussion}

The discussion of the study is organized based on two issues: the teachers' and academic staff's conception of research as reported in the questionnaire and their research engagement as reported in the online survey and interview.

\section{Teachers and Academic Staff's Conceptions of Research}

The survey data showed that scenarios number $6,4,2$, and 5 ranked $1^{\text {st }}$ to $4^{\text {th }}$ consecutively (see Table 2 and Appendix 3), indicating that these four scenarios were perceived as 'research' by more participants compared to the other scenarios. The participants appeared to align 'research' with evidencebased practice (Scenario \#6), survey (Scenario \#4), literature-driven practice and professional communication (Scenario \#2), and observation-based popular 
article (Scenario \#5). This finding is similar to that of Borg (2009) and Banegas (2018) in which the participants' conception of research is largely linked to those five features. Both teachers and academic staff in the present study saw that research has to include pre-test and post-test, dependent and independent variables, and significant evidence of why a particular method is more effective than the others. They felt they need to engage with and in research so that they can have pedagogical judgements based on a literature review or an investigation on which approach is more effective than the other. The participating teachers and academic staff also believed that research has to incorporate a big amount of data that can be gathered from survey or questionnaire, is observable, and has to be disseminated to others. As a form of data gathering, in addition to survey or questionnaire, observations also appear to be more familiar to both teachers and academic staff rather than other data collection methods.

The survey data also revealed that both teachers and academic staff were less certain about most of the scenarios (see Table 2). Six out of 10 scenarios (Scenario 1, 10, 3, 7, 8 \& 9) were perceived as probably not research. Table 2 shows that an action-research-like or a trial-and-error process (Scenario 1), a qualitative survey-based scientific article (Scenario 10), a literature-led discussion (Scenario 3), and learner feedback driven teaching practice (Scenarios $8 \&$ 9), and a teacher-informed report (Scenario 7) were assessed as probably not research. These results also mirrored what Borg (2009) and Banegas (2018) have found. They also relate to the other findings of the present study in which making experiments on which teaching methods is more effective than the others is seen as research (Scenario 6) rather than just making a personal self-reflection (Scenario 1). Similarly, a questionnaire with more than 400 participants is seen as research (Scenario 4) rather than a study on others' written reflection (Scenario 9) or a literature-based study (Scenario 3). It can therefore be understood that the teachers' and academic staff's conceptions of research in the present study are associated with the conventional scientific enquiry (Borg, 2009), such as, being objective, using hypotheses testing, and being practical.

The results of the survey also showed that the scenarios which were least defined as a research activity were Scenarios 1 and 8 . Scenario 1 is: "A teacher noticed that an activity she used in class did not work well. She thought about this after the lesson and made some notes in her diary. She tried something different in her next lesson. This time the activity was more successful." Scenario 8 is: "Mid-way through a course, a teacher gave a class of 30 students a feed- 
back form. The next day, five students handed in their completed forms. The teacher read these and used the information to decide what to do in the second part of the course". Most teachers and academic staff did not see these two scenarios as research. A possible explanation for this might be that they do not see a trial-and-error process and learner feedback driven teaching practice as research.

It is interesting to note that for Scenario 3, 7, 9 and 10, the survey data showed a total opposite result for academic staff and teachers. Teachers thought those four scenarios were probably not research but academic staff believed that they were probably research. This might be explained by the fact that teachers and academic staff perceive research differently. Academic staff perceive a literature-led discussion, a teacher-informed report, a learner feedback driven teaching practice, and a qualitative survey-based scientific investigation as research while teachers are not convinced if those scenarios are categorized as research. In other words, teachers in the present study perceive that if a study does not investigate people, is done by others (in the scenario, for instance, by the headmaster for teachers or by Head of the English department for his/her staff), and investigates qualitative data (i.e., essays), it is not a research or not a teacher research.

Thus, it can be concluded that teachers see teacher research as an activity that was done by and for themselves. This notion is in contrast with one of the Banegas' findings (2018) in his study. In his study Banegas (2018) found that teacher research was perceived as studies carried out by other professionals rather than by teachers themselves. The finding of the survey in the present study that Scenario 7 (that teacher research is the one done by professional to them) was perceived by teachers as a non-research scenario was in line with the interview results in which teachers mentioned about doing classroom action research for their promotion. The teachers in this study believed that teacher research (i.e., action research) should be done by the teachers themselves to improve their teaching. Hence, the teachers' conceptions in the study posit the notion of teacher research that is different from what was defined by the participants in the Banegas' study (2018).

It is interesting to note that in all 10 scenarios in the questionnaire, Scenario 6 ranked the highest among the EFL teachers compared to the other scenarios. On the other hand, Scenario 4 ranked the highest among the EFL academic staff and the teachers participating in Borg's studies $(2009,2010)$ and Scenario 2 
ranked the highest in Banegas' study (2018). This discrepancy might be due to teachers' and academic staff's perceived understanding of what a research is and the shared research cultures among Indonesian teachers. Scenario 6 looks into finding the most effective and efficient method between two teaching methods by comparing the results of pre and post-test. Scenario 6 is the most likely scenario that can happen in the classrooms and is probably the most familiar one to the EFL teachers' day to day activities in Indonesian context.

Scenario 4 came second among Indonesian teachers in the present study and in Banegas' study (2018). However, this scenario came first among the academic staff in the present study and in Borg's studies $(2009 ; 2010)$. The different views might be explained by the use of some key words in the fourth scenario. Scenario 4 uses the key words: university, lecturer, questionnaire, statistics, article, and academic journal. These key words were central to teachers' conceptions of the kind of activity that research involves (Borg, 2009: 366), especially for nonIndonesian participants in Borg's study and for both teachers and academic staff in the present study. The interviews also confirmed that some teachers and academic staff in Indonesia were struggling with issues in reading academic literature, doing the research, writing up the results of the research they did, and publishing the results of their studies in the academic journals. It can therefore be concluded that Scenario 4 came second among the Indonesian teachers because the scenario indicated more challenges for them compared to Scenario 6.

Together the findings of the study provide some crucial insights into teachers' and academic staff's conceptions of research. First, the teachers' and academic staff's conceptions of research evolve around the ideas of evidencebased practice, survey, literature-driven practice and professional communication, observation-based popular article, and survey-based professional communication. Second, reflective inquiry, narrative inquiry, and literary based research designs were deemed unfamiliar as ways to collect data. Third, the first insight is true to both groups of respondents, teachers $(N=259)$ and academic staff $(N=139)$. However, the second insight is supposedly true for teachers. These findings indicate that teachers and academic staff are more familiar with some types of research designs than the others and thus, they find some designs to be more challenging than the others. In other words, future professional development programs for teachers and academic staff should be able to cater the needs of the teachers and academic staff. New research designs 
might need to be introduced and continuous mentoring needs to be done to ensure the success of the programs. More research collaboration between teachers and academic staff need to be realized. Thus, teachers and academic staff do not only understand the concept of teacher research but also do it well.

\section{Teachers' and Academic Staff's Research Engagement}

Reflecting upon the teachers' engagement in research, the present study showed that few teachers (and academic staff) read published research reports but quite a few of them (teachers and academic staff) did research. The results were similar to those of Borg (2009, p. 377) and Banegas (2018, p. 63).

It could be concluded that personal (I enjoy it), pedagogical (I find better ways of teaching) and professional (it is good for my professional development) motives were the participants' main drives to do research. While this finding broadly supports Borg's work (2009), it does not confirm Borg's ideas on how external drives such as promotion and employer pressure received less emphasis (p. 376). In the present study, external drives in terms of job promotion were strong among school teachers and were even stronger among academic staff in the university.

The interview data revealed that internal and external supports were viewed as the key factors to the success and failure of teacher research among teachers and academic staff, which is similar to what was suggested by Bai (2018), Banegas (2018), Borg $(2009,2010)$ and Chow et al. (2015). In the present study, the internal factors that challenged teacher research were lack of interest, lack of motivation, and lack of need to do research. The external factors included lack of time, lack of incentives, lack of supports, and lack of academic atmosphere. Regarding support for teacher research, the present study found that professional awareness, personal passion, and solving classrooms' issues were pivotal internal factors, while the external factors that support research especially for the academic staff were professional obligations, job promotions, and financial incentives. With regard to promotions, it is interesting that achieving higher position is one of the most cited motivations for both academic staff and teachers in the present study.

This study also showed that academic staff claimed to read and do research more frequently compared to school teachers. The latter finding is foreseeable. With research as part of the Indonesian academic staff's Tri Dharma Perguruan Tinggi or Three Pillars of Higher Education, i.e., Teaching, Researching, and 
Community Service, research is an inseparable part of the academic staff's duty. For teachers at schools, research is an obligation, too, at a certain level, if they want to get a promotion; however, if they have not reached that particular level, they are not obliged to do research to fulfil the requirements for their promotion. This finding confirms what Utami and Prestridge (2018) found regarding Indonesian English teachers' professional development (PD) dispositions that are affected by professional development (PD) policies. They use the term 'compliant disposition' (2018, p. 259) for policy-driven professional development, e.g., doing research as they are obliged to for their promotion. The opposite disposition is 'indifferent disposition' (p. 259), which refers to selfdriven professional development regardless of the policy demand. In relation to the present study's finding, compliant disposition seems to be the explanation for the different research engagements between academic staff and teachers.

Another interesting finding of the present study relates to the financial aspect of teacher research. While competitive research grants from the Indonesian Directorate General of Research and Higher Education (DGHE) are made available for academic staff and students at the universities (Wiryawan, 2014), no information is available on where and how teachers can obtain research grants from the Ministry of Education and Culture or other ministries. This indicates how PD policy may cause tension between how things need to be done by certain standard (accountability) and what needs to be done for teacher learning (authenticity) (Su et al., 2017).

Overall, the study confirms our argument that that teachers' and academic staff' engagement with and in teacher research, as defined by Borg (2010), is never straightforward. Clearly, aspects such as teachers' cognitive understanding of what teacher research is, how to do it, and how to obtain practical supports have to be considered to create more research friendly cultures and more positive improvement and engagement among teachers and academic staff.

\section{CONCLUSIONS}

The present study shows that EFL teachers have fewer engagements in teacher research compared to the academic staff. This might be due to their lack of understanding of the concept of "teacher research" as well as its benefits for teachers' continuous professional development. Policy makers need to ensure that professional development (PD) policy could encourage and support school 
teachers to do research as part of their continuing professional development. On the other hand, while the study shows that academic staff receive better supports and have stronger personal motivation to do teacher research, there are still rooms for improvement in the quantity and the quality of their research.

Overall, the results of this study suggest that the challenges of teacher research persist and research engagement relies heavily upon the teachers and academic staff's nature of their professional development's expectations and supports from relevant institutions. There is a need to find solutions to problems faced by EFL teachers at schools, to maintain or boost the research engagement among academic staff, and to explore the best form of a continuous professional development which integrates teacher research into both teachers' and academic staff's routine teaching responsibilities. There is, therefore, a definite need for collaborative teacher research initiatives among academic staff and teachers. This should be done to ensure that if teachers have lack of understanding and what might help them is the existence of mentors, academic staff may assist them by becoming their mentors. This bottom-up initiative could go hand in hand with a more top-down approach where universities also launch initiatives to assist teachers as well as their academic staff to actively engage in collaborative research. A similar idea has received sufficient supports in different countries such as at Sultanate of Oman, Chile, Taiwan, and China (Al-Maamari et al., 2017; Bai, 2018; Burns et al., 2016; Burns \& Westmacott, 2018; Chen, 2015; Chow et al., 2015).

Finally, a key policy priority should therefore be planned for some shortterm and long-term goals in both schools and universities by teachers and headmasters at schools and by academic staff and relevant stakeholders in the university level. These may encompass needs analysis to understand the rationale for promoting teacher research engagement, ways to conceptualize research, washback effect on teachers' research engagement, teachers' current understanding of and attitudes toward research engagement, specific and realistic targets of research activities, and kinds of supports teachers need to meet those targets (Borg \& Liu, 2013). The long-term goals may include strategies to keep the collaborative teacher research initiatives sustainable and productive for several years. 
384 TEFLIN Journal, Volume 32, Number 2, July 2021

\section{ACKNOWLEDGEMENTS}

We are especially indebted to Dr. Willy A Renandya for his input on the initial draft of this article.

\section{FUNDING}

This research received no specific grants from any funding agency in the public, commercial, or not-for-profit sectors.

\section{REFERENCES}

Abbuhl, R. (2011). Why, when, and how to replicate research. In A. Mackey \& S. M. Gass (Eds.), Research methods in second language acquisition: A practical guide (pp. 296-312). John Wiley \& Sons.

Al-Maamari, F., Al-Aamri, K., Khammash, S., \& Al-Wahaibi, M. (2017). Promoting EFL teacher research engagement through a research support programme. RELC Journal, 48(3), 389-404. https://doi.org/10.1177/0033688216684282

Bai, L. (2018). Language teachers' beliefs about research: A comparative study of English teachers from two tertiary education institutions in China. System, 72, 114-124. https://doi.org/10.1016/j.system.2017.11.004

Banegas, D. L. (2018). Towards understanding EFL teachers' conceptions of research: Findings from Argentina. Profile: Issues in Teachers' Professional Development, 20(1), 57-72. https://doi.org/10.15446/profile.v20n1.61881

Battaglia, P. J. (2008). Purposive sample. In P. J. Lavrakas (Ed.), Encyclopaedia of survey research methods (pp. 524-527). Sage Publications. https://doi.org/10.4135/9781412963947.n419

Borg, S. (2009). English language teachers' conceptions of research. Applied Linguistics, 30(3), 358-388. https://doi.org/10.1093/applin/amp007

Borg, S. (2010). Language teacher research engagement. Language Teaching, 43(4), 391-429. https://doi.org/10.1017/S0261444810000170

Borg, S. (2013). Teacher research in language teaching: A critical analysis. Cambridge University Press.

Borg, S., \& Liu, Y. (Daphne). (2013). Chinese college English teachers' research engagement. TESOL Quarterly, 47(2), 270-299. https://doi.org/10.1002/tesq.56 
Wulyani et al., English Language Teachers' Views of Teacher Research 385

Borg, S., \& Sanchez, H. S. (2015). Key issues in doing and supporting language teacher research. In S. Borg \& H. S. Sanchez (Eds.), International perspectives on teacher research (pp. 1-14). Palgrave Macmillan.

Braun, V., \& Clarke, V. (2006). Using thematic analysis in psychology. Qualitative Research in Psychology, 3(2), 77-101. https://doi.org/10.1191/1478088706qp063oa

Burns, A., \& Westmacott, A. (2018). Teacher to researcher: Reflections on a new action research program for university EFL teachers. Profile: Issues in Teachers' Professional Development, 20(1), 15-23. https://doi.org/10.15446/profile.v20n1.66236

Burns, A., Westmacott, A., \& Ferrer, A. H. (2016). Initiating an action research programme for university EFL teachers: Early experiences and responses. Iranian Journal of Language Teaching and Studies, 4(3), 55-73. https://doi.org/10.30466/ijltr.2016.20354

Çelik, S., \& Dikilitaş, K. (2015). Action research as a professional development strategy. In S. Borg \& H. S. Sanchez (Eds.), International perspectives on teacher research (pp. 125-139). Palgrave Macmillan.

Chen, C. Y. (2015). A study showing research has been valued over teaching in Higher Education. Journal of the Scholarship of Teaching and Learning, 15(3), 15-32. https://doi.org/10.14434/josotl.v15i3.13319

Chow, K., Chu, S. K. W., Tavares, N., \& Lee, C. W. Y. (2015). Teachers as researchers: A discovery of their emerging role and impact through a school-university collaborative research. Brock Education Journal, 24(2), 20-39. https://doi.org/10.26522/brocked.v24i2.374

Creswell, J. W. (2014). Research design: Qualitative, quantitative, and mixed methods approaches $\left(4^{\text {th }}\right.$ ed.). SAGE Publications.

Dikilitaş, K., \& Yayli, D. (2018). Teachers' professional identity development through action research. ELT Journal, 72(4), 415-424. https://doi.org/10.1093/elt/ccy027

Friedman, D. A. (2012). How to collect and analyze qualitative data. In A. Mackey \& S. M. Gass (Eds.), Research methods in second language acquisition (pp. 180-200). John Wiley \& Sons, Ltd. https://doi.org/10.1002/9781444347340.ch10

Medgyes, P. (2017). The (ir)relevance of academic research for the language teacher. ELT Journal, 71(4), 491-498. https://doi.org/10.1093/elt/ccx034 
Richards, J. C., \& Farrell, T. S. C. (2005). Professional development for language teachers. Cambridge University Press.

Su, Y., Feng, L., \& Hsu, C.-H. (2017). Accountability or authenticity? The alignment of professional development and teacher evaluation. Teachers and Teaching, 23(6), 717-728. https://doi.org/10.1080/13540602.2016.1255189

Tran, A., Burns, A., \& Ollerhead, S. (2017). ELT lecturers' experiences of a new research policy: Exploring emotion and academic identity. System, 67, 6576. https://doi.org/10.1016/j.system.2017.04.014

Utami, I. G. A. L. P., \& Prestridge, S. (2018). How English teachers learn in Indonesia: Tension between policy-driven and self-driven professional development. TEFLIN Journal, 29(2), 245-265. https://doi.org/10.15639/teflinjournal.v29i2/245-265

Wiryawan, K. G. (2014). The current status of science journals in Indonesia. Science Editing, 1(2), 71-75. https://doi.org/10.6087/kcse.2014.1.71 
Wulyani et al., English Language Teachers' Views of Teacher Research 387

\section{Appendix 1}

\section{Survey Questions}

Link: https://bit.um.ac.id/Appendix_1_Survey

\section{Appendix 2}

\section{Interview Guide}

1. Do you read research reports, theses, dissertations, and/or scholarly journal articles? Why or why not?

2. If yes, what research reports, theses, dissertations, and/or scholarly journal articles do you read? What for?

3. If reading scholarly journal articles, mention the name of the journal(s).

4. Do you or your friends do research? Why or why not?

5 . What kind of research do you or your friends do?

6. Can you mention any problems you have in reading and doing research?

7. Can you mention any incentives/facilities/assistance you have in reading and doing research?

8. Do you have any suggestions, comments, ideas, opinions about teachers' engagement in reading and doing research?

\section{Appendix 3}

Ten research scenarios taken from Borg (2009, pp. 378-380)

(1) A teacher noticed that an activity she used in class did not work well. She thought about this after the lesson and made some notes in her diary. She tried something different in her next lesson. This time the activity was more successful.

(2) A teacher read about a new approach to teaching writing and decided to try it out in his class over a period of two weeks. He video recorded some of his lessons and collected samples of learners' written work. He analyzed 
this information then presented the results to his colleagues at a staff meeting.

(3) A teacher was doing an MA course. She read several books and articles about grammar teaching then wrote an essay of 6000 words in which she discussed the main points in those readings.

(4) A university lecturer gave a questionnaire about the use of computers in language teaching to 500 teachers. Statistics were used to analyze the questionnaires. The lecturer wrote an article about the work in an academic journal.

(5) Two teachers were both interested in discipline. They observed each other's lessons once a week for three months and made notes about how they controlled their classes. They discussed their notes and wrote a short article about what they learned for the newsletter of the national language teachers' association.

(6) To find out which of two methods for teaching vocabulary was more effective, a teacher first tested two classes. Then for four weeks she taught vocabulary to each class using a different method. After that she tested both groups again and compared the results to the first test. She decided to use the method which worked best in her own teaching.

(7) A headmaster met every teacher individually and asked them about their working conditions. The head made notes about the teachers' answers. He used his notes to write a report which he submitted to the Ministry of Education.

(8) Mid-way through a course, a teacher gave a class of 30 students a feedback form. The next day, five students handed in their completed forms. The teacher read these and used the information to decide what to do in the second part of the course.

(9) A teacher trainer asked his trainees to write an essay about ways of motivating teenage learners of English. After reading the assignments the trainer decided to write an article on the trainees' ideas about motivation. He submitted his article to a professional journal.

(10) The Head of the English department wanted to know what teachers thought of the new course book. She gave all teachers a questionnaire to complete, studied their responses, then presented the results at a staff meeting. 